\title{
The Impact of Executive Compensation on Banking Performance: Evidence from the Ghanaian Banking Crises
}

\author{
Emmanuel Anyigbah1, Yusheng Kong1, Ahotovi Thomas Ahoto², Wilhelmina Seyome Ahiaku1 \\ ${ }^{1}$ School of Finance and Economics, Jiangsu University, Zhenjiang, China \\ ${ }^{2}$ School of Management, Jiangsu University, Zhenjiang, China \\ Email: eanyigbah@gmail.com
}

How to cite this paper: Anyigbah, E., Kong, Y.S., Ahoto, A.T. and Ahiaku, W.S. (2021) The Impact of Executive Compensation on Banking Performance: Evidence from the Ghanaian Banking Crises. Open Access Library Journal, 8: e8045.

https://doi.org/10.4236/oalib.1108045

Received: October 3, 2021

Accepted: October 25, 2021

Published: October 28, 2021

Copyright $\odot 2021$ by author(s) and Open Access Library Inc.

This work is licensed under the Creative Commons Attribution International License (CC BY 4.0).

http://creativecommons.org/licenses/by/4.0/

\begin{abstract}
During the period 2012-2018, nine Ghanaian banks went bankrupt, causing depositors and shareholders to lose billions of Ghana Cedis. This development stunned the whole Ghanaian community, as many had not anticipated the occurrence of a banking crisis of that magnitude, since most of these banks were renowned indigenous banks. One of the fundamental causes of these banks' failure was a lack of sound corporate governance practices. In this regard, the current study attempts to focus on one of the corporate governance practices-executive compensation-by giving an in-depth analysis of how poor executive compensation contributed to the failure of these banks. The study found that there was weak adherence to common execution compensation principles and practices of corporate governance. Banks did not have the appropriate compensation systems designed for the banks' executives and non-executives. In addition, the compensation committee of some banks was not properly constituted whereas others had no compensation committee.
\end{abstract}

\section{Subject Areas}

Accounting, Corporate Governance, Financial Reporting

\section{Keywords}

Executive Compensation, Banking Crisis, Banking Performance, Collapsed Banks, Corporate Governance

\section{Introduction}

The global financial crisis began when Enron, WorldCom, and other American firms went bankrupt due to accounting and compensation scandals, resulting in 
a loss of investor confidence and a drop in shareholder value [1]. Since this event, regulatory authorities worldwide, including those in developed and developing countries, have proposed various legislations and stricter corporate governance standards to reestablish investor trust while safeguarding the interests of the company's owners [2].

Similarly, in Ghana between 2012 and 2018, seven banks and several other non-banking financial institutions went down, causing depositors and shareholders to lose billions of Ghana Cedis. As a result, the licenses of two commercial banks-UT Bank and Capital Bank, were revoked by the Bank of Ghana in 2017 [3]. Eight months down the lane, other seven commercial banks also collapsed, and the Bank of Ghana revoked their licenses [4]. These seven other banks were amalgamated to form the Consolidated Bank Ghana, whereas the earlier collapsed two banks were acquired by another bank "GCB bank" at the instance of the regulator. The ramifications of this banking failure have had several adverse effects on Ghana's economy [5]. Apart from the number of Ghanaians who have lost employment, analysts estimate that over 400,000 jobs have been affected [6]. The Ghanaian government also lost several million dollars throughout the process, investing about 600 million dollars into banks before their collapse to revive them, but this goal could not be achieved. Additionally, many Ghanaians have lost faith in the banking industry as a result of this.

The reasons behind these banks' failures were investigated and recorded. The report found illegal practices where some chief executive officers or managing directors engaged in illicit financial transfers without directors' permission. The conclusion of the preliminary reports by the Bank of Ghana and the KPMG points to an absence or failure of good corporate governance practice among the banks [4]. In this respect, the current study intends to focus on one of the corporate governance mechanisms, executive compensation, by providing a deeper understanding of the following issues: Could the CEOs and the executives have averted this corporate failure? Were their compensations gratifying enough to commensurate and enhance the performance of the banks?

Executive compensation has been of much concern to policymakers, academia, and other stakeholders, creating a general perception that executive compensations of CEOs and executives are excessive and not correlated to the performance of the banks [7]. Furthermore, in the face of weak corporate governance principles and legislation, CEOs and executives set their compensations at an outrageous constraint [8]. Executive compensations refer to the remuneration packages given to CEOs and the executives who are charged with the responsibility of managing the affairs of organizations. These are financial payments and non-monetary benefits provided to the high-level management in exchange for their work on behalf of the company. The remuneration packages typically include; cash compensation (salary, annual bonus) and equity compensation (stock options and restricted shares) [9].

Before the global financial crisis of 2007-2008, the majority of empirical research on executive compensation focused on the non-financial sectors. The fi- 
nancial crises elicited a range of reactions and questions from academia, the media, regulators, and other stakeholders, including: 1) whether bank executives were overpaid; 2) whether their compensation induced CEOs to take the excessive risk; 3) and, from a public policy perspective and whether the government should regulate financial institutions' executive compensation packages. Whereas some scholars believed that excessive risk-taking by bank CEOs is the significant factor that contributed to the financial crises [10], while the other group opined that there is no correlation between what is being paid to the bank CEOs and excessive risk-taking [11] [12].

Given the inconclusive results regarding the relationship between CEOs' compensation and bank performance, the current study reexamines the link between these two using data from the annual reports of the nine collapsed Ghanaian Banking Institutions. By this, we ask the following question: Is the perceived relatively high and apparent increases in bank executive compensation over the years correlated to bank performance?

The inspiration for this study is to investigate the sudden collapse of these banks in Ghana, because, these were renowned banks and well celebrated in the country, therefore, the sudden collapse was least anticipated. Also, the study investigated the executive compensation principles and practices in a developing economy's indigenous banks. Most researches on executive compensation focus predominantly on firms other than financial institutions. Therefore, this study endeavors to fill the gap by investigating indigenous banks in Ghana.

The principal objective of this study is to tap into the actual adherence to executive compensation principles and practices of the collapsed banks and more importantly to dive into the relationship of the practices and their related impact on banking performance.

The study reveals weak adherence to executive compensation principles and practices among the collapsed banks in Ghana.

The study contributes to the discussion on corporate governance issues specifically on executive compensation and its impacts on banking performance in Ghana in the areas of composition, design, transparency, accountability, and independence.

This paper is further organized as follows; Section 2 discusses the literature review which focuses on Banking in Ghana and corporate governance, in addition, the agency theory and compensation plans, Executive compensation and banking performance are discussed. Section 3 also focuses on executive compensation principles and practices of corporate governance (composition, design, transparency, accountability, and independence). Section 4 explains the findings and discussions on executive compensation issues and lastly. Section 5 draws the conclusions from the study and makes recommendations.

\section{Literature Review}

\subsection{Banking in Ghana and Corporate Governance}

Ghana's banking sector consists of the central bank, various commercial banks, 
development banks, merchants' banks, and a slew of rural banks [13]. The Monetary Policy Committee (MPC) governs the industry, established statutorily under the Bank of Ghana Act to develop monetary policy, and is solely monitored by the Bank of Ghana (BoG). Historically, Ghana's banking sector was dominated by state-owned institutions and lacked competitiveness. However, throughout the last few decades, state-owned banks have been privatized as part of the government's divestiture implementation initiatives, which resulted in the privatization of some Agricultural Development Banks (ADB), Ghana Commercial Banks (GCB), and others.

Following the Basel Committee on Banking Supervision's corporate governance principles, the BoG published notices and directions on governance structures and control systems for banks and specialist deposit-taking institutions. However, in December 2018, in response to the collapse of several banks, the BoG issued its own comprehensive corporate governance code for the banking industry, specifically banks, savings and loans companies, finance houses, and financial holding companies licensed or registered under the Banks and Specialist Deposit-Taking Institutions Act 2016 [14]. The BoG issued the Fit and Proper Person Directive in July 2019 to promote solid corporate governance standards and prohibit ineligible persons from engaging in any regulated activity. The purpose of this directive is to create a framework that allows financial institutions and the Bank of Ghana to decide whether a person is qualified to serve as a director, a significant shareholder, or a senior manager in a financial organization. All of these directives, including the corporate governance codes, are mandatory and, in some situations, have implementation dates. Additionally, compliance with the various laws and constitutions applicable to listed companies is compulsory, except in certain limited circumstances when the appropriate supervisory body may grant waivers of certain specific provisions or requirements subject to certain conditions imposed by the supervisory body.

Corporate governance principles have received significant attention in Ghana's banking industry, owing to many legislations governing banking activities [15]. Ghana's corporate governance code regulates every stage of firm creation [15]. As a result, Ghana has many monitoring procedures to guarantee that banks adhere to sound corporate governance practices. These monitoring mechanisms are designed to promote excellent corporate governance practices among Ghanaian businesses. They include the Ghana Companies Act 1963 (Act 179), the Economic and Organized Crime Office Act (Act 408), the Criminal Code (causing financial loss Act 29), the Ghana Banking Act 1986 (PNDCL 225), and the Bank of Ghana regulations [4].

\subsection{The Agency Theory and Compensation Plans}

According to agency theory, management compensation arises from the separation of ownership and control. To ensure that managers' interests align with those of the owners, these shareholders must implement incentive contracts and effective monitoring methods. According to [16] and [17], a positive relationship 
between management compensation and bank performance aligns with shareholders' interests. The theory asserts that the principal-agent relationship is made up of the shareholder who is the principal and the executive directors are the agents. To help mitigate agency problems, in which managers pursue objectives that conflict with those of the shareholders, shareholders employ executive compensation to urge managers to act in the shareholders' interest rather than their own. This theory is important to this work as it will form the basis of our analysis.

Executive compensation is one of the corporate governance mechanisms that align CEOs' and executives' interests with the shareholders through salary, bonuses, and long-term incentives such as stock options. Therefore, compensation plans are frequently of various forms. According to [9] compensation is divided into two categories: cash-based compensation (basic salary, annual bonuses, pension contributions, and allowances) and equity-based compensation (stock options, restrictions). In the absence of a specified form of compensation, executives are likely to set up their own compensation to the disadvantage of the shareholders.

\subsection{Executive Compensation and Banking Performance}

According to agency theory, CEOs' and executives' incentives can align with shareholder preferences via compensation systems that compensate the CEO and other executives based on the bank's performance. Therefore, there have been several studies on the relationship between executive compensation and firm performance in various jurisdictions with no definite conclusions drawn. There have been two opposing views held by researchers who have attempted to examine this relation. Some documented a positive relationship [18] [19], while others noted a negative relationship [19] [20]. Some also saw no connection [21]. Although the relationship between these two variables is still debatable, most studies undertaken in the last two decades have produced a substantial amount of evidence in favor of the idea that firm performance positively affects executive compensation [22] [23] [24] [25].

In previous studies, researchers employed accounting-based performance indicators such as profit, return on equity, and return on assets [26], as well as market-based performance measures such as stock prices and total shareholder return to measure firms' performances [27]. Companies must redefine performance and how to measure it. They must covey the unique values of the company, explore non-traditional pay models to attract rare talents, focus on the balance of short-term interest and long-term values to retain key talents in the new environment [28].

\section{Executive Compensation Principles and Practices of Corporate Governance}

Sound compensation policies and practices are critical for long-term and sustainable performance for shareholders. Executive compensation is essential to retaining the most capable executives and setting high standards for the banks' 
performance in generating long-term shareholder value [29]. To reflect the above, executive compensation packages for banks' executives must be based on the standard principles and practices to motivate managers to maximize shareholders' wealth [30]. This section discusses the principles and practices associated with executive compensation namely; the composition of the executive package of both executive and non-executive directors, design of the compensation policy, transparency of plans, accountability, and independence. The study draws its analysis based on the annual reports of UT bank and uniBank Ghana from the period of the commencement of business until December 2016 to determine their executive compensation principles and practices. A descriptive analysis is adopted to explain the outcomes.

\subsection{Composition}

The bank shall have a precise composition of the compensation package of the executives and non-executives [31]. The banks' compensation package should create long-term shareholder value and not incentivize excessive risk-taking to align management and shareholders' interest [32]. In terms of the composition of the compensation package for both executives and non-executive directors, UT Bank constantly throughout its 9 years of operation did not provide a separate compensation package for the banks' executive and non-executives. The executive compensation was made in total for the executives without specifying the detailed components of the compensation; this is in contravention of the requirements for executive compensation systems for financial institutions in Ghana. However, uniBank on the other hand provided a separate compensation package for the executives and non-executive directors of the bank.

\subsection{Design}

The banks' compensation policy should be clear, comprehensive, and discuss the relevant components of the compensation in full detail [33]. The intended forms of incentives, bonuses, and others should be detailed. This shall include cash compensations comprising basic salary, annual bonuses, pension contributions, and allowances) and equity-based compensation (stock, options, restrictions) [34]. In contributing to value creation over the long term, incentives should be structured to reward performance. The structured design package should consider whether the banks will have a fixed, variable, or mix of these two compensation systems. When executives' compensation is tied to Pay for performance is used, the banks should also be clear and measure such performances against set targets to prevent excessive risk-taking [35]. Also, executive compensation issues relating to contractual engagements and termination of appointments should be clearly stated.

Table 2 depicts UT Bank's executive compensation plan which does not give details on issues such as how non-executive directors and executive directors are compensated, the components of the compensation plan whether cash, equity or mixed as stipulated in the industry standard. This can make the bank's execu- 
tives set their compensation which may be outrageous and may not be in the interest of the shareholders. Furthermore, UT Bank disclosed the shares held by the bank's executives for only two consecutive years of operation while the disclosure for the rest of the years was forfeited. However, uniBank Ghana separately compensates its executives and non -executives but according to the bank's disclosure in its shareholdings structure, none of its executive directors own shares in the bank.

\subsection{Transparency}

The well-designed compensation plan eventually enhances efficiency and reduces the instances in which the bank executives and the investors are taken by surprised the compensation programs [36]. Therefore, there should be full disclosure of such plans. Transparency builds trust between the shareholders and the executives. UT Bank and uniBank Ghana, among the nine banks, did not disclose their compensation plans. This makes it easy for the bank's executives to set their compensation at the expense of its shareholders. This practice is not in conformity with the industry standard of financial institutions.

\subsection{Accountability}

The compensation committee is responsible for designing, implementing, evaluating, and monitoring the compensation program [37]. The roles and responsibilities of the compensation committee shall be clearly defined and stated to avoid any ambiguity in carrying out those roles and responsibilities about the compensation plans [38]. These plans shall ultimately be submitted to the shareholders for approval. With regards to the compensation committee, although UT Bank had compensation committee for only two years, throughout its operations for the 9 years, uniBank Ghana did not have a compensation committee for its years of operation. This governance structure and policy of the bank is contradictory to the industry standard for financial institutions in Ghana.

\subsection{Independence}

The compensation process shall be conducted by an independent committee member utilizing independent advisors and compensation consultants [39]. The independence of the compensation committee of UT Bank is compromised as its composition is made up of non-executive directors instead of independent directors. This may affect the role of the committee exercising its responsibilities independently. In the case of uniBank Ghana, it had no compensation committee for its years of operation that also contradicts the standard for financial institutions.

\section{Findings and Discussions on Executive Compensation Issues}

Following the collapse of the banks in Ghana, the authors try to investigate the causes of the banks' failure using executive compensation principles and practices as stipulated in the corporate governance code for Financial Institutions in 
Ghana. The study examined the executive compensation system relating to the composition, design, transparency, accountability, and independence to ascertain if the collapsed nine banks followed the prescribed regulations. Banks are to be devoted to the adherence of strong corporate governance practices about executive compensation. The study reveals weak adherence to CG practices especially, executive compensation system relating to principles and practices among the collapsed banks in Ghana. Table 1 shows the number of banks which collapsed and the year of establishments. According to Table 2, out of the nine collapsed banks, only UT bank and uniBank Ghana'spublished annual reports could be assessed, making the rest of the banks contradicting the disclosure and transparency policy for financial institutions in Ghana. From Table 3, however, executive compensation reported in the annual reports of the UT Bank was not designed to show how the executives of the bank were to be compensated either by cash compensation based or equity compensation based or both as compared to the industry standard. Furthermore, the composition of the compensation packages for the banks' executives and non-executives were not detailed for all the banks, especially as seen in the case of UT Bank. However, in Table 4, uniBank

Table 1. The collapsed banks.

\begin{tabular}{cc}
\hline NAME OF BANK & YEAR OF ESTABLISHMENT \\
\hline UT Bank & 2009 \\
Capital Bank & 2009 \\
Unibank Ghana Ltd. & 1997 \\
The Royal Bank Ltd & 2012 \\
Beige Bank Ltd. & 2017 \\
Sovereign Bank Ltd. & 2015 \\
Construction Bank Ltd. & 2016 \\
Premium Bank Ltd. & 2016 \\
Heritage Bank Ltd. & 2016 \\
\hline
\end{tabular}

Source: Bank of Ghana, 2018.

Table 2. Annual reports disclosure and transparency.

\begin{tabular}{ccccccccc}
\hline NAME OF BANK & 2009 & 2010 & 2011 & 2012 & 2013 & 2014 & 2015 & 2016 \\
\hline UT Bank & A & A & A & A & A & A & NA & NA \\
Capital Bank & NA & NA & NA & NA & NA & NA & NA & NA \\
UniBank Ghana Ltd. & NA & NA & NA & NA & NA & NA & A & A \\
The Royal Bank Ltd. & & & & NA & NA & NA & NA & NA \\
Beige Bank Ltd. & & & & & & & \\
Sovereign Bank Ltd. & & & & & & NA & NA \\
Construction Bank Ltd. & & & & & & & NA \\
Premium Bank Ltd. & & & & & & & & NA \\
Heritage Bank Ltd. & & & & & & & NA \\
\hline
\end{tabular}

Source: Authors' Compilation. A-Available; NA-Not Available. 
Table 3. Executive compensation plan of UT Bank, Ghana.

\begin{tabular}{|c|c|c|c|c|c|c|c|c|}
\hline Compensations & 2009 & 2010 & 2011 & 2012 & 2013 & 2014 & 2015 & 2016 \\
\hline $\begin{array}{l}\text { Directors' Comp.: } \\
\text { Executive }\end{array}$ & 216,000 & 328,000 & 413,000 & 457,000 & 426,000 & 433,000 & NA & NA \\
\hline Ownership & NA & NA & A & A & NA & NA & NA & NA \\
\hline $\begin{array}{l}\text { Remuneration } \\
\text { Committee }\end{array}$ & NA & NA & A & A & NA & NA & NA & NA \\
\hline
\end{tabular}

Source: Authors' compilation. A-Available; NA—Not Available; Dir Comp.—Directors Compensation.

Table 4. Executive compensation plan of uniBank Ghana.

\begin{tabular}{ccccccccc}
\hline Compensations & $1997-2009$ & 2010 & 2011 & 2012 & 2013 & 2014 & 2015 & 2016 \\
\hline $\begin{array}{c}\text { Directors' Comp.: } \\
\text { Executive }\end{array}$ & NA & NA & NA & NA & NA & NA & $2,789,836$ & $3,397,951$ \\
$\begin{array}{c}\text { Non-Executive } \\
\text { Ownership }\end{array}$ & NA & NA & NA & NA & NA & NA & 411,225 & 352,875 \\
$\begin{array}{c}\text { Remuneration } \\
\text { Committee }\end{array}$ & NA & NA & NA & NA & NA & NA & NA & NA \\
\hline
\end{tabular}

Source: Authors' compilation. A-Available; NA-Not Available; Dir Comp.—Directors Compensation; Exec.-Executive.

Ghana, although provided a separate compensation package for its executive and non-executive directors, it was not clear whether the executives were only entitled to cash-based compensation or otherwise.

Also, from Table 3, UT Bank had no remuneration committee for all the years it operated as stipulated in the standard except for only 2011 \& 2012 of the existence of the committee. Again, in the case of uniBank Ghana, from Table 4, the bank had no compensation committee throughout its years of operation. This practice, if not curbed, could result in issues such as; CEOs and other executives could set their compensations higher at an outrageous constraint that is not in the interest of the shareholders. Executives may also appear to favor their compensations by linking it to performance when they can manipulate the performance measures to their advantage such that investors will not realize it.

Remuneration committees have the responsibility to initiate and review executive compensation packages. These committees are essential because they are responsible for ensuring that executive compensation systems are in the best interest of shareholders. The remuneration committee develops the bank's compensation plans subject to the shareholders' approval at their Annual General Meeting (AGM). From Table 5, UT Bank, although, had a compensation committee for two years, it compromised on the composition of the committee. The committee was composed of non-executive directors instead of independent directors as stipulated in the corporate governance code for the financial institution in Ghana. Non-executive directors (NED) are members of a company's board of directors who are not part of the executive team and so, do not engage in the day-to-day management of the company. They may or may not own shares of the company. Independent non-executive directors (INEDs) are members of 
Table 5. Remuneration committee composition of UT Bank, Ghana.

\begin{tabular}{cccc}
\hline Years & Committee size & \multicolumn{2}{c}{ Committee Independence } \\
\hline & & Non-exec. Dir. (NEDs) & Ind. Non-exec. Dir. (INEDs) \\
$2011 \& 2012$ & 3 & 3 & 0 \\
\hline
\end{tabular}

Source: Authors' compilation.

Table 6. Financial institutions' standard for executive compensation.

\begin{tabular}{|c|c|}
\hline $\begin{array}{c}\text { Executive Compensation } \\
\text { Principles }\end{array}$ & Suggested Industry Standard Practice \\
\hline Design & $\begin{array}{l}\text { - The board should oversee the compensation system spearheaded by } \\
\text { the remuneration committee and monitor it to align it with prudent } \\
\text { risk-taking. } \\
\text { - Must be sufficient to attract, retain and motivate executive officers but } \\
\text { must be balanced against the bank's interest and not pay excessive } \\
\text { remuneration. } \\
\text { - Avoid excessive risk-taking when remuneration is tied to performance } \\
\text { - No sitting allowance, directed fees for the executive directors, whereas } \\
\text { non-executive directors would be entitled to such benefits. } \\
\text { - Equity-based remuneration such as share option shall be tied to } \\
\text { performance subject to shareholders' approval at AGM. }\end{array}$ \\
\hline Transparency & Shares held by executives shall be disclosed in annual reports. \\
\hline Independence & Independent directors shall determine the compensation of the executives. \\
\hline
\end{tabular}

Source: [40]: Bank of Ghana, 2018.

the board who do not have any monetary relationship with the company or own any shares except with their renumeration. Since uniBank Ghana had no compensation committee throughout its years of operation, the committee's composition was unknown.

Table 6 outlines the standardized provisions for executive composition principles and practices for financial institutions in Ghana.

\section{Conclusion and Recommendations}

In conclusion, UT Bank and uniBank Ghana failed to adhere to laid down principles and practices relating to executive compensation, and therefore, this contributed to one of their woes to succeed in the banking industry.

So, the banks in Ghana should strictly adhere to good corporate governance practices and be guided by the corporate governance code developed by the bank of Ghana. Additionally, the banks shall adhere to good practices and embrace executive compensation guidelines for executive and non-executive directors.

There should be a well-designed compensation system for both executives and non-executives, which should be fair and reasonable, considering the labor market conditions and the company's responsibility at law, which should be relative to the scale of the banks' business.

Again, when compensation is linked to performance, targets must be set. The targets should be connected to the bank's short-, medium- and long-term per- 
formance objectives that show the purpose, values, strategic goals, and avoid excessive risk-taking, which happened during the crises where executives had to make a cash transfer without approval from the company's boards.

Lastly, there should be a well-designed equity-based compensation that includes options and performance rights.

\section{Acknowledgements}

This is research is funded by National Natural Science Foundation of China (No. 71371087).

\section{Conflicts of Interest}

The authors declare no conflicts of interest.

\section{References}

[1] Toms, S. (2019) Financial Scandals: A Historical Overview. Accounting and Business Research, 49, 477-499. https://doi.org/10.1080/00014788.2019.1610591

[2] Haddad, A.E., et al. (2017) Accounting Legislation, Corporate Governance Codes and Disclosure in Jordan: A Review. International Journal of Law and Management, 59, 147-176. https://doi.org/10.1108/IJLMA-07-2016-0064

[3] Osei, A.A., et al. (2019) Collapse of Big Banks in Ghana: Lessons on Its Corporate Governance.

[4] Maama, H., et al. (2019) Institutional Investors, Corporate Governance and Firm Performance: Evidence from Emerging Economy. African Journal of Business and Economic Research, 14, 91-109. https://doi.org/10.31920/1750-4562/2019/14n3a5

[5] Amuakwa-Mensah, F., Marbuah, G. and Ani-Asamoah Marbuah, D. (2017) Re-Examining the Determinants of Non-Performing Loans in Ghana's Banking Industry: Role of the 2007-2009 Financial Crisis. Journal of African Business, 18, 357-379. https://doi.org/10.1080/15228916.2017.1308199

[6] Quansah, S. (2019) The Effect of Banking Crises on Employees in Ghana: The Case of Consolidated Bank Ghana. University of Ghana, Accra.

[7] Keller, W. and Olney, W. (2021) Globalization and Executive Compensation. Journal of International Economics, 129, Article ID: 103408. https://doi.org/10.1016/j.jinteco.2020.103408

[8] Vaneylen, M. (2017) The Relationship between CEO Compensation and Company Performance and Risk. Master of Science in Business Economics, University of Ghent, Ghent.

[9] Lovett, S., Rasheed, A.A. and Hou, W. (2021) Stock Options, Restricted Stock, Salary, or Bonus? Managing CEO Compensation to Maximize Organizational Performance. Business Horizons. https://doi.org/10.1016/j.bushor.2021.02.041

[10] Iqbal, J. and Vähämaa, S. (2019) Managerial Risk-Taking Incentives and the Systemic Risk of Financial Institutions. Review of Quantitative Finance and Accounting, 53, 1229-1258. https://doi.org/10.1007/s11156-018-0780-z

[11] Gande, A. and Kalpathy, S. (2017) CEO Compensation and Risk-Taking at Financial Firms: Evidence from US Federal Loan Assistance. Journal of Corporate Finance, 47, 131-150. https://doi.org/10.1016/j.jcorpfin.2017.09.001

[12] Altunbaş, Y., Thornton, J. and Uymaz, Y. (2020) The Effect of CEO Power on Bank 
Risk: Do Boards and Institutional Investors Matter? Finance Research Letters, 33, Article ID: 101202. https://doi.org/10.1016/j.frl.2019.05.020

[13] YuSheng, K. and Ibrahim, M. (2019) Service Innovation, Service Delivery and Customer Satisfaction and Loyalty in the Banking Sector of Ghana. International Journal of Bank Marketing, 37, 1215-1233. https://doi.org/10.1108/IJBM-06-2018-0142

[14] Assibey-Yeboah, M.D. (2019) Report of the Finance Committee on the Request for Approval of the Sum of Fifteen Billion, Six Hundred Million Ghana Cedis (GHC 15.6 Billion) to Protect Depositors and Investors of Failed Financial Institution and Improve Liquidity of the Financial Sector.

[15] Baldavoo, K. and Nomlala, B. (2019) Audit Quality and Corporate Governance as Determinants of Banks' Performance in Ghana. Acta Universitatis Danubius. Economica, 15, 228-242.

[16] Amis, J., et al. (2020) From the Editors-Why We Need a Theory of Stakeholder Governance-And Why This Is a Hard Problem. Academy of Management Review, 45, 499-503. https://doi.org/10.5465/amr.2020.0181

[17] Paniagua, J., Rivelles, R. and Sapena, J. (2018) Corporate Governance and Financial Performance: The Role of Ownership and Board Structure. Journal of Business Research, 89, 229-234. https://doi.org/10.1016/j.jbusres.2018.01.060

[18] Elsayed, N. and Elbardan, H. (2018) Investigating the Associations between Executive Compensation and Firm Performance: Agency Theory or Tournament Theory. Journal of Applied Accounting Research, 19, 245-270. https://doi.org/10.1108/JAAR-03-2015-0027

[19] Bennett, B., Bettis, J.C., Gopalan, R. and Milbourn, T. (2017) Compensation Goals and Firm Performance. Journal of Financial Economics, 124, 307-330. https://doi.org/10.1016/j.jfineco.2017.01.010

[20] Aslam, E., Haron, R. and Tahir, M. (2019) How Director Remuneration Impacts Firm Performance: An Empirical Analysis of Executive Director Remuneration in Pakistan. Borsa Istanbul Review, 19, 186-196. https://doi.org/10.1016/j.bir.2019.01.003

[21] Saidu, S. (2019) CEO Characteristics and Firm Performance: Focus on Origin, Education and Ownership. Journal of Global Entrepreneurship Research, 9, Article No. 29. https://doi.org/10.1186/s40497-019-0153-7

[22] Sheikh, M.F., Shah, S.Z.A. and Akbar, S. (2018) Firm Performance, Corporate Governance and Executive Compensation in Pakistan. Applied Economics, 50, 2012-2027. https://doi.org/10.1186/s40497-019-0153-7

[23] Wu, H., et al. (2018) Politically Connected CEOs, Firm Performance, and CEO Pay. Journal of Business Research, 91, 169-180. https://doi.org/10.1016/j.jbusres.2018.06.003

[24] Smirnova, A.S. and Zavertiaeva, M. (2017) Which Came First, CEO Compensation or Firm Performance? The Causality Dilemma in European Companies. Research in International Business and Finance, 42, 658-673.

https://doi.org/10.1016/j.ribaf.2017.07.009

[25] Omoregie, O.K. and Kelikume, I. (2017) Executive Compensation and Banking Sector Performance: Evidence from Nigeria. The Journal of Developing Areas, 51, 1-15. https://doi.org/10.1353/jda.2017.0027

[26] Şamiloğlu, F., et al. (2017) The Determinants of Firm Financial Performance: Evidence from Istanbul Stock Exchange (BIST). IOSR Journal of Economics and Finance, 8, 62-67.

[27] Bendle, N.T. and Butt, M. (2018) The Misuse of Accounting-Based Approximations 
of Tobin's Q in a World of Market-Based Assets. Marketing Science, 37, 484-504. https://doi.org/10.1287/mksc.2018.1093

[28] Li, X. (2020) Literature Review of Executive Compensation. Journal of Service Science and Management, 13, 153-167. https://doi.org/10.4236/jssm.2020.131010

[29] Lazonick, W. (2017) The Functions of the Stock Market and the Fallacies of Shareholder Value. In: Driver, C. and Thompson, G., Eds., Corporate Governance in Contention, Oxford University Press, Oxford, 117-151. https://doi.org/10.2139/ssrn.2993978

[30] Magnan, M. and Martin, D. (2019) Executive Compensation and Employee Remuneration: The Flexible Principles of Justice in Pay. Journal of Business Ethics, 160, 89-105. https://doi.org/10.1007/s10551-018-3786-5

[31] Birhanu, A.G., et al. (2021) Acquisition Experience and Director Remuneration. Journal of International Financial Markets, Institutions and Money, 75, Article ID: 101356. https://doi.org/10.1016/j.intfin.2021.101356

[32] Gomez-Mejia, L.R., Neacsu, I. and Martin, G. (2019) CEO Risk-Taking and Socioemotional Wealth: The Behavioral Agency Model, Family Control, and CEO Option Wealth. Journal of Management, 45, 1713-1738.

https://doi.org/10.1177/0149206317723711

[33] Kotnik, P., Sakinç, M.E. and Guduras, D. (2018) Executive Compensation in Europe: Realized Gains from Stock-Based Pay. SSRN Electronic Journal. https://doi.org/10.2139/ssrn.3228809

[34] Villalobos, M.L. (2017) Forecasting Shareholder Value from Equity-Based Compensation. Northcentral University, Scottsdale.

[35] Rahim, R. and Husni, T. (2020) The Relation between Cash Compensation of Banking Executives, Charter Value, Capital Requirements and Risk Taking. International Journal of Business, 25, 399-420.

[36] Bordo, M.D. and Levin, A.T. (2019) Digital Cash: Principles \& Practical Steps. National Bureau of Economic Research, Cambridge. https://doi.org/10.3386/w25455

[37] Chin, M. and Semadeni, M. (2017) CEO Political Ideologies and Pay Egalitarianism within Top Management Teams. Strategic Management Journal, 38, 1608-1625. https://doi.org/10.1002/smj.2608

[38] Maas, K. (2018) Do Corporate Social Performance Targets in Executive Compensation Contribute to Corporate Social Performance? Journal of Business Ethics, 148 , 573-585. https://doi.org/10.1007/s10551-015-2975-8

[39] Harvey, C., Maclean, M. and Price, M. (2020) Executive Remuneration and the Limits of Disclosure as an Instrument of Corporate Governance. Critical Perspectives on Accounting, 69, Article ID: 102089.

https://doi.org/10.1016/j.cpa.2019.06.003

[40] Ghana, B.O. (2018) Corporate Governance Directive 2018. https://www.bog.gov.gh/notice/the-banking-business-corporate-governance-directi ve-2018 